\title{
電流遮断法による単結晶シリコン陽極酸化の解析
}

\author{
柚賀 正光*, 竹内 学 ${ }^{* *}$, 大山 昌憲 ${ }^{* * *}$
}

\section{Analysis of Anodic Oxidation of Single Crystalline Si by Current Interruption}

\author{
Masamitsu YUGA*, Manabu TAKEUCHI** and Masanori OHYAMA***
}

\begin{abstract}
Current interruption was used to measure silicon dioxide layer capacitance and Si oxidation activation energy at $20 \sim 70^{\circ} \mathrm{C}$.

A current interrupter was built using an electromagnetic relay and integrated circuits. When Si was anodized in an ethylene glycol solution, the current between the n-type Si wafer anode and Pt cathode was interrupted for $5 \mathrm{~ms}$ on galvanostatic electrolysis, and the transient phenomena of voltage waveform, form which short term anodic oxidation kinetic parameters are obtained, were observed by a digital memory scope.

Oxide film capacitance increased rapidly beyond a current density of $1 \mathrm{~mA} \mathrm{~cm}^{-2}$. Oxide film capacitance increased with electrolyte temperature up to about $40^{\circ} \mathrm{C}$, but decreased as temperature increased from $45^{\circ} \mathrm{C}$ to $50^{\circ} \mathrm{C}$. Activation energy for silicon anodic oxidation was about $23.7 \mathrm{~kJ} \mathrm{~mol}^{-1}$ over $55^{\circ} \mathrm{C}$ and $122 \mathrm{~kJ} \mathrm{~mol}^{-1}$ at $20 \sim 40^{\circ} \mathrm{C}$.

Key Words: Anodic Oxidation, Single Crystalline Silicon, Current Interrupter, Activation Energy for Anodic Oxidation
\end{abstract}

\section{1. 緒言}

半導体素子作製において半導体表面に酸化膜を成長さ せる工程は重要である。シリコンは，現在最も広く用い られている半導体であるが, シリコン表面に安定した酸 化膜を成長させるには $1100^{\circ} \mathrm{C}$ 以上の高温が必要である。 酸化膜成長装置の維持管理やコストの面を考えると,よ り低温で酸化膜を成長させられることが望ましい。

低温でシリコンに酸化膜を成長させる方法に陽極酸化 法がある。この方法では, 電解液中に素材のシリコンを 浸漬し直流電圧を印加することにより簡単に酸化膜を成 長させることができる。また，アモルファスシリコンの ように高温酸化が不可能な素材にも適用できる。従来の 研究では, 単結晶シリコン表面に陽極酸化法を用いて成 長させた膜は, ウェットな工程を含むので, 高温酸化膜 に比較して膜質が劣る ${ }^{1)}$ とされていた。しかし，酸化膜 成長の設定電圧の調整によっては, 陽極酸化でもかなり 高品質の酸化膜形成が可能である ${ }^{2)}$ 。

* 茨城大学 大学院理工学研究科（テ316-8511 茨城県日立市 中成沢町 4-12-1)

Graduate School of Sci. and Eng., Ibaraki Univ. (4-121, Nakanarusawa-cho, Hitachi-shi, Ibaraki 316-8511)

**茨城大学 工学部 ( $316-8511$ 茨城県日立市中成沢町 412-1)

Dept. of Electrical and Electronic Eng., Ibaraki Univ. (4 -12-1, Nakanarusawa-cho, Hitachi-shi, Ibaraki 3168511)

*** 東京工業高等専門学校 電気工学科（T193-8610 東京都八 王子市椚田町 1220-2)

Dept. of Electrical Eng., Tokyo National College of Technology (1220-2, Kunugida-cho, Hachioji-shi, Tokyo 193-8610)
著者らは陽極酸化法を用いてシリコン表面に酸化膜を 成長させるとき, 成長温度を室温 $70^{\circ} \mathrm{C}$ 範囲で変化さ せて, シリコンと酸化膜界面をXPS 分析により解析し たところ, 得られる酸化膜の膜質が $45^{\circ} \mathrm{C}$ おいて大き

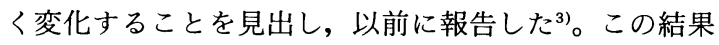
は, 酸化膜の膜質は成長温度により変化し, 条件によっ ては安定した酸化膜を得られる可能性を示唆する。

本研究では, 単結晶シリコン表面に陽極酸化法を用い て酸化膜を成長させるとき, 表面に成長しつつある酸化 膜の容量と反応に必要な活性化エネルギーの成長温度依 存性を検討した。そのため, 電極を介して流す定電流を 微少時間遮断して電極間の電圧波形を観測し, 過渡応答 特性から分極特性を考察した。その結果, XPS 分析と 同様に, 成長温度 $45^{\circ} \mathrm{C}$ 付近を境として, 酸化膜の容量 と反応の活性化エネルギーに著しい変化が観測された。 特に陽極酸化反応に必要な活性化エネルギーは, 低温側 と高温側で数值が大きく異なり, 今回は以前のアモル ファスシリコンの解析 ${ }^{4)}$ では観測されなかった結果を得 たので報告する。

\section{2. 実験方法}

本実験で用いた陽極酸化測定システムを図 1 に示す。 図中の陽極酸化セルは温度制御された恒温槽中に置かれ

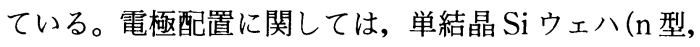
$10^{15} \mathrm{~cm}^{-3} \mathrm{P}$ ドープ)を陽極, $\mathrm{Pt}$ 板を陰極とした。電解 液としてエチレングリコール溶液(含 $0.04 \mathrm{kmol} \mathrm{m}^{-3}$ $\left.\mathrm{HNO}_{3}\right)$ を用いた。電極を介して流す定電流を微少時間 遮断するための回路は, IC および水銀接点の電磁り レーを用いて自作した4)。電流の遮断時間は $5 \mathrm{~ms}$ とし 


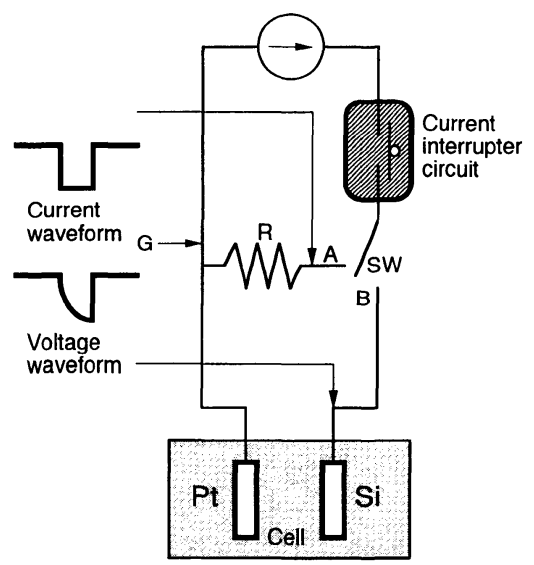

Fig. 1 Current interrupting system for analysis of an anodic oxidation of silicon wafer.

た。遮断時間の調整はつぎのように行った。まずスイッ チ (SW) を回路に挿入した基準抵抗 $\mathrm{R}$ 側 (A 点)に倒すと, 抵抗の両端 (A-G 間)の波形観測から電流波形が得られ る。その電流波形を見ながら電流遮断回路中の抵抗とコ ンデンサを調整し遮断時間を設定した。つぎに，SWを セル側(B 点)に倒す。このときが陽極酸化の開始時点で あり, 電極間 (B-G 間)の電圧波形観測を行った。なお, 出力の電圧波形はデジタルメモリースコープで観測し, データをGP-IBによりコンピュータに取り込んで，過 渡応答特性の解析を行った。

電圧波形の過渡応答特性の解析方法を図 2 に示す。図 $2(\mathrm{a}) に$ 電極間の等価回路を示した。 $R_{\mathrm{r}}$ は電解液の抵抗, $R_{\mathrm{e}}$ は酸化膜の抵抗， $C_{\mathrm{d}}$ は成長過程での酸化膜容量であ る。この回路に電流 $i$ を流し, 時間 $t=0$ において電流 を遮断したとき電流波形が図 2 (b)である。遮断する時間 は $5 \mathrm{~ms}$ であり通電時間の数\%と短いので, 電流を遮断 すると反応は一時的に停止するが, 定電流陽極酸化の状 態として近似される。電流を遮断している間の電圧波形 は，図 2 (c)のようになる。電流を遮断した瞬間に液抵抗 分の電圧降下が生じる。この值を $e_{0}$ とする。その後容 量 $C_{\mathrm{d}}$ があるので, 通電を開始するまで電圧は過渡応答 特性を示す。

その場合，次の(1)式が成立する。

$$
i-i_{\mathrm{f}}=i_{\mathrm{d}}=C_{\mathrm{d}}(d e / d t)
$$

ここで

\section{$i_{1}:$ 電極反応電流 \\ $i_{\mathrm{d}}:$ 酸化膜充電電流 \\ $e:$ 電極電位}

である。さらに，i は(2)式の関係があるので，(3)式を得 る。

$i_{\mathrm{f}}=-i_{0} \exp \left\{\alpha n F\left(e-e_{\mathrm{e}}\right) / R T\right\}$

$i+i_{0} \exp \left\{\alpha n F\left(e-e_{\mathrm{e}}\right) / R T\right\}=C_{\mathrm{d}}(d e / d t)$

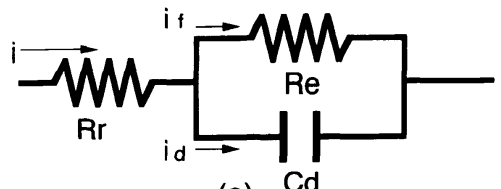

(a)

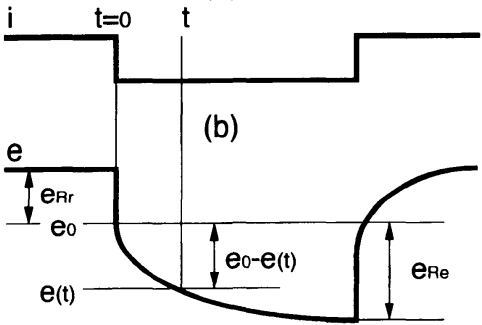

(c)

Fig. 2 (a) Equivalent circuit of the cell for the anodic oxidation of silicon wafer.

(b) Current waveform.

(c) Voltage waveform.

初期条件を $e(0)=e_{0}$ として, 遮断中の電圧 $e_{0}-e(\mathrm{t})$ は，(3)式で示す微分方程式を解くことにより得られる5)。 ここで

$i_{0}:$ 酸化膜形成反応の交換電流密度

$e_{\mathrm{e}}$ : 酸化膜と電解液界面の平衡電位

$R:$ 気体定数

$T:$ 絶対温度

$\alpha:$ 移動係数

$n$ : 反応電子数

$F:$ ファラデー定数

である。一般解は，次の(4)式となる。

$e_{0}-e(\mathrm{t})=(R T / \alpha n F) \ln \left(1+\alpha n F i t / R T C_{\mathrm{d}}\right) \cdots(4)$

上式において, $B=R T / \alpha n F$ (定数) とおくと,

$e_{0}-e(\mathrm{t})=B \ln \left(1+i t / B C_{\mathrm{d}}\right)$

となる。

$i t / B C_{\mathrm{d}} \gg 1$ の領域では,

$e_{0}-e(\mathrm{t})=B \ln \left(i / B C_{\mathrm{d}}\right)+B \ln t$

であるので, $e_{0}-e(\mathrm{t})$ と $\ln t$ の関係をプロットすれば直 線となる。このプロットにおいて， $e_{0}-e(\mathrm{t})$ をゼロに外 挿して得られる $t=t_{\mathrm{d}}$ を用いると，

$$
i t_{\mathrm{d}} / B C_{\mathrm{d}}=1
$$

となり， $C_{\mathrm{d}}$ の值を計算することができる。

一方, 図 2 において, 通電が開始される直前の $e_{\mathrm{Re}}$ は 経験的に

$$
e_{\mathrm{Re}}=A+B \ln i \quad(\mathrm{~A}, \mathrm{~B} \text { は定数 })
$$

と表わすことができ， $e_{\mathrm{Re}}$ と $\ln i$ の間には直線関係があ る。このとき， $e_{\mathrm{Re}}$ をゼロに外挿して得られる電流の値 $i_{0}$ は反応の交換電流密度とよばれる。 $i_{0}$ の温度に関する アレニウスプロットは,

$i_{0}=K \exp (-E / R T)$ 
であるので, $\ln i_{0}$ と $1 / T$ のプロットの直線の傾きから 陽極酸化反応に必要な活性化エネルギーE を求めるこ とができる。

\section{3. 結果および考察}

電流の遮断は充分な通電後短時間行われるが, 通電時 間が 4〜10 分程度経過すると初期段階での酸化膜が成長 し安定する。そのため, 通電後 5 分経過した場合の電流 遮断時の電圧波形を観測した。

電解液温度 $20^{\circ} \mathrm{C}$ のきの $e_{0}-e(\mathrm{t})$ と $\ln t$ の関係を図 3 に示す。結果は電流密度が $2.5,5.0,7.5,10.0 \mathrm{~mA}$ $\mathrm{cm}^{-2}$ の場合である。 $t$ が大きい領域で直線性を満足す る。温度を変化させ測定した結果も同様な傾向を示した。 これらの直線をゼロに外插して得られた值 $t_{\mathrm{d}}$ を用いて $C_{\mathrm{d}}$ の值を計算した結果を図 4 および図 5 に示す。図 4 は $C_{\mathrm{d}}$ の電流密度依存性を示し, 図 5 は $C_{\mathrm{d}}$ の電解液温

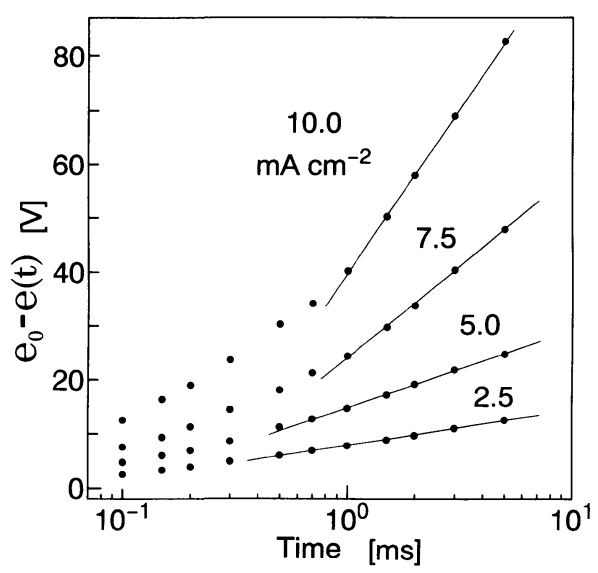

Fig. 3 Voltage $e_{0}-e(\mathrm{t})$ as a function of time for various choices of current densities at $20^{\circ} \mathrm{C}$.

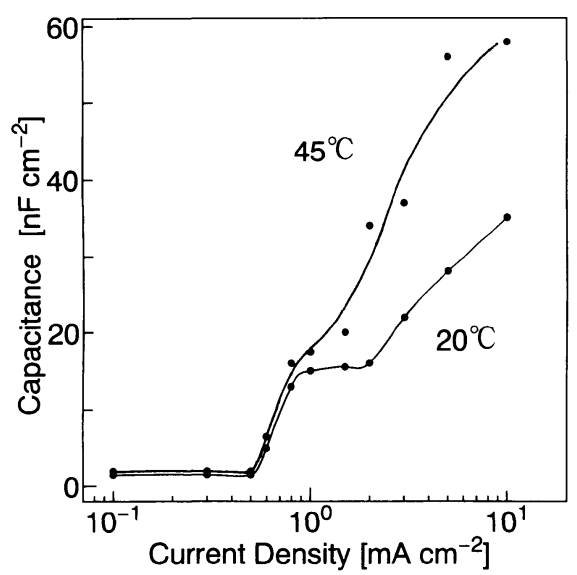

Fig. 4 Calculated capacitance of the oxide films as a function of current density at 20 and $45^{\circ} \mathrm{C}$.
度依存性を示している。

図 4 は電解液温度が $20^{\circ} \mathrm{C}$ と $45^{\circ} \mathrm{C}$ 場合であるが，特 徵として $1 \mathrm{~mA} \mathrm{~cm}^{-2}$ 付近を境として $C_{\mathrm{d}}$ の值は急激に増 加する傾向が認められる。電流密度が $1 \mathrm{~mA} \mathrm{~cm} \mathrm{~cm}^{-2}$ より 小さい条件では電解反応があまり進行せず，酸化膜はほ とんど成長していないと考えられる。電流密度が $1 \mathrm{~mA}$ $\mathrm{cm}^{-2}$ 以上になると酸化膜の成長が促進されるが， $C_{\mathrm{d}}$ の 値が増加していることから, 酸化膜の厚みはそれほど増 加せず表面の山凸が大きくなるものと考えられる。これ は，酸化膜にかかる電界が表面全域において完全に均一 でないことによる6)。図 4 に示した温度以外でも同様の 傾向が見られた。

図 5 は $C_{\mathrm{d}}$ の電解液温度による変化であり, 電流密度 $2.5,5.0,10.0 \mathrm{~mA} \mathrm{~cm}{ }^{-2}$ の場合を示した。 $40^{\circ} \mathrm{Cまでの}$ 低温側では, 電解液温度の上昇につれて $C_{\mathrm{d}}$ の值は増加 していくが，45〜 50 $\mathrm{C}$ 付近においてやや減少を示した。

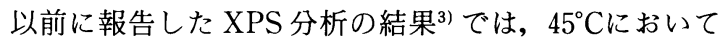
シリコン酸化膜 $\mathrm{SiO}_{2}$ の $\mathrm{Si} 2 \mathrm{p}$ ピークがシリコン基板の 内部においても減少せず, 酸化膜が $\mathrm{Si}$ 基板に入り込み, 結果として見かけの酸化膜の厚みが増加して容量が減少 するという結論を得た。しかしそれは，初め定電流電解 を行って酸化膜を成長させ, 電圧が既定値 $(200 \mathrm{~V})$ に達 した後, 充分定電圧電解を行って表面の均一性を高めた 試料の分析結果であった。今回の実験においては，定電 流電解期間中での陽極酸化反応解析における容量の值で あるので,一律に論ずることはできないが，反応が定電 流で進行する過程においても 45〜 $50^{\circ} \mathrm{C}$ 付近において酸 化膜容量が減少するという観測結果が得られた。このこ とから，定電流で酸化膜が成長する過程においても，反 応は電解液温度に深く依存していることがわかる。

$e_{\mathrm{Re}}$ と $\ln i$ の直線関係より得た交換電流密度の温度依

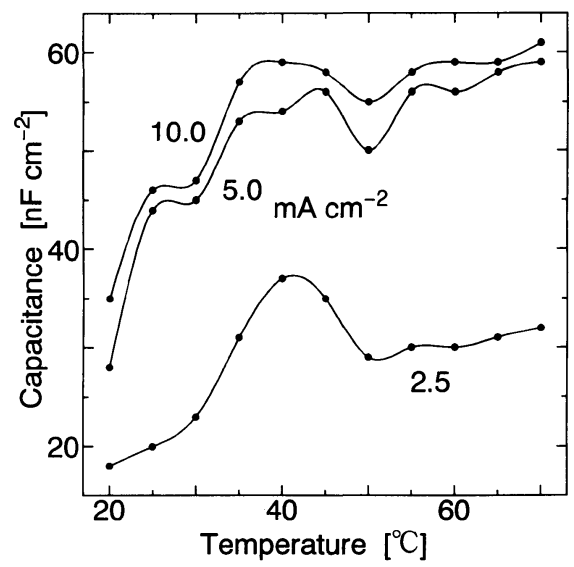

Fig. 5 Calculated capacitance of the oxide films as a function of temperature at the current densities of $2.5 \sim 10 \mathrm{~mA} \mathrm{~cm}^{-2}$. 


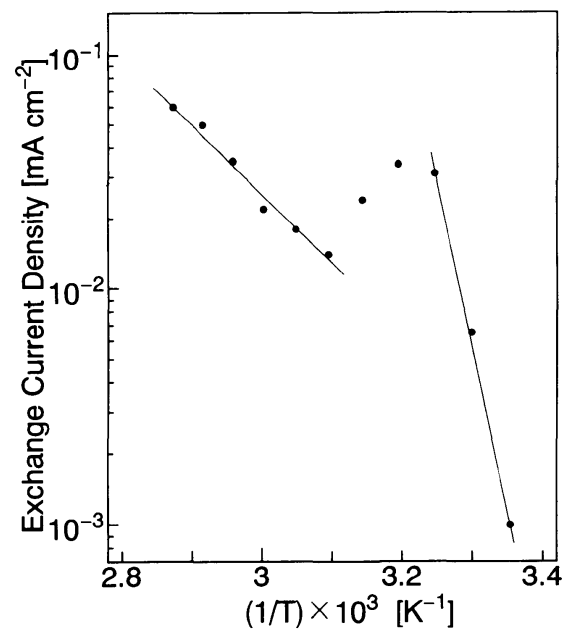

Fig. 6 Relationship between logarithmic exchange current density and reciprocal absolute temperature.

存性のアレニウスプロットを図 6 に示す。直線の傾きか ら陽極酸化反応に必要な活性化エネルギーが計算できる。 図 6 では， $45^{\circ} \mathrm{C}$ を境として高温側と低温側に傾きの異な る二つの直線が存在する。図 6 の二本の直線より, 本研 究で用いた単結晶シリコンの陽極酸化の活性化エネル ギーは $55 \sim 70^{\circ} \mathrm{C}$ 高温側で $23.7 \mathrm{~kJ} \mathrm{~mol}^{-1}, 20 \sim 40^{\circ} \mathrm{C}$ の 低温側で $122 \mathrm{~kJ} \mathrm{~mol}^{-1}$ と求められた。

一方, プラズマ CVD 法を用いて成長させたアモル ファスシリコンの陽極酸化を電流遮断法により解析した 結果では, 本研究と同一の温度範冊においてアレニウス プロットは一つの直線となり, 陽極酸化の活性化エネル ギーは $14.5 \mathrm{~kJ} \mathrm{~mol}^{-1}$ であった4)。本研究の単結晶シリ コンで得られた高温側の活性化エネルギーの值はアモル ファスシリコンの值と近いことが確認された。つまり， 低温側では陽極酸化には大きなエネルギーが必要である
が, $40 \sim 50^{\circ} \mathrm{C}$ 付近に境界領域が存在し, 高温側では比較 的低エネルギーで酸化膜が成長することが判明した。境 界領域の温度では $C_{\mathrm{d}}$ の值が減少するので, 酸化膜の膜 厚が増加しているものと考えられる。

\section{4. 結言}

単結晶シリコン表面に低温で酸化膜を成長させる陽極 酸化を解析した。定電流電解で反応が進行するとき, 酸 化膜の容量と反応の活性化エネルギーの電解液温度依存 性を考察するため, 電極間の電流を微少時間遮断し, そ の間の過渡応答特性の観測から各パラメータの計算を 行った。

その結果, 電流密度 $1 \mathrm{~mA} \mathrm{~cm} \mathrm{~cm}^{-2}$ 付近を境として酸化 膜の成長が急激に促進されることが判明した。また，電 解液温度を $20 \sim 70^{\circ} \mathrm{C}$ 範囲で変化させて酸化膜容量と 成長の活性化エネルギーを測定したところ，45〜 $50^{\circ} \mathrm{Cを}$ 境として高温側と低温側で大きく異なる值が得られた。 さらにこの境界温度において, 酸化膜の膜厚の増加によ る容量の隇少を見出した。

(Received July 31, 1998 ; Accepted January 14, 1999)

\section{文献}

1) E. F. Duffek, E. A. Benjamini and C. Mylroie ; Electrochemical Technology, 3, 75(1965)

2) G. C. Jain, A. Prasad and B. C. Chakravarty ; J. Electrochem. Soc., 126, 89 (1979)

3 ) 柚賀正光, 吉岡学洋, 竹内 舞, 高橋三男, 大山昌憲; 表面技 術, 47, 607 (1996)

4 ）柚賀正光, 赤沢 昇, 山崎 珠, 大山昌憲；表面技術, 43, 335 (1992)

5 ）仁木克己, 高橋正雄 ; 電気化学, 39, 909 (1971)

6 ) R. M. Burger, R. P. Donovan ; Fundamentals of Slicon Integrated Device Technology, pp.41４3（地人書館, 1970） 